\title{
Article \\ Influence of Phosphorus Sources on the Compressive Strength and Microstructure of Ferronickel Slag-Based Magnesium Phosphate Cement
}

\author{
Cuirong Yan ${ }^{1,2}$, Hongyan Ma ${ }^{3}{ }^{\mathbb{D}}$, Zhongqiu Luo ${ }^{1, *}$, Xintao Zhou ${ }^{1, *}$ and Luxing Wang ${ }^{1}$ \\ 1 Faculty of Chemical Engineering, Kunming University of Science and Technology, Kunming 650500, China; \\ huaxiarong@126.com (C.Y.); wlx1234562022@163.com (L.W.) \\ 2 Faculty of Environmental and Chemical Engineering, Kunming Metallurgy College, Kunming 650033, China \\ 3 Department of Civil, Architectural and Environmental Engineering, Missouri University of Science and \\ Technology, Rolla, MO 65401, USA; mahon@mst.edu \\ * Correspondence: luozhongq@126.com (Z.L.); zhouxt@kust.edu.cn (X.Z.)
}

check for updates

Citation: Yan, C.; Ma, H.; Luo, Z.; Zhou, X.; Wang, L. Influence of Phosphorus Sources on the Compressive Strength and Microstructure of Ferronickel Slag-Based Magnesium Phosphate Cement. Materials 2022, 15, 1965. https://doi.org/10.3390/ ma15051965

Academic Editor: Hubert Rahier

Received: 14 January 2022

Accepted: 14 February 2022

Published: 7 March 2022

Publisher's Note: MDPI stays neutral with regard to jurisdictional claims in published maps and institutional affiliations.

Copyright: (C) 2022 by the authors. Licensee MDPI, Basel, Switzerland. This article is an open access article distributed under the terms and conditions of the Creative Commons Attribution (CC BY) license (https:// creativecommons.org/licenses/by/ $4.0 /)$.

\begin{abstract}
Electric furnace ferronickel slag (EFS) is a typical magnesium-rich industrial by-product discharged from the manufacture of nickel and iron-nickel alloys. The approach to use it as the raw material for the preparation of magnesium phosphate cement (MPC) has potential and proves effective. In this study, three different phosphorus sources (PS) including phosphoric acid $\left(\mathrm{H}_{3} \mathrm{PO}_{4}, \mathrm{PA}\right)$, sodium dihydrogen phosphate $\left(\mathrm{NaH}_{2} \mathrm{PO}_{4}, \mathrm{SDP}\right)$ and potassium dihydrogen phosphate $\left(\mathrm{KH}_{2} \mathrm{PO}_{4}\right.$, PDP) were used to react with EFS to prepare the EFS-based MPC (EMPC), and the effects of raw material mass ratio (EFS/PA, EFS/SDP, EFS/PDP) on the compressive strength, early hydration temperature and microstructure of EMPC pastes were investigated. Results showed that the compressive strength of EMPC paste is significantly impacted by the type of phosphorus source and the raw materials mass ratio. When the EFS/PDP ratio is 4.0, the compressive strength of the MPC paste reaches up to $18.8,22.8$ and $27.5 \mathrm{MPa}$ at 3, 7 and $28 \mathrm{~d}$, respectively. Cattiite $\left(\mathrm{Mg}_{3}\left(\mathrm{PO}_{4}\right)_{2} \cdot 22 \mathrm{H}_{2} \mathrm{O}\right), \mathrm{K}$-struvite $\left(\mathrm{KMgPO}_{4} \cdot 6 \mathrm{H}_{2} \mathrm{O}\right)$ and / or Na-struvite $\left(\mathrm{NaMgPO}_{4} \cdot 6 \mathrm{H}_{2} \mathrm{O}\right)$ were identified as the main hydration products of EMPC. The development of EMPC mainly involves the dissolution of a phosphorus source, $\mathrm{MgO}$ and $\mathrm{Mg}_{2} \mathrm{SiO}_{4}$, formation of hydration product as binder, and combination of the unreacted raw materials together by binders to build a compact form.
\end{abstract}

Keywords: magnesium phosphate cement; electric furnace ferronickel slag; phosphorus source; hydration product

\section{Introduction}

Electric furnace ferronickel slag (EFS) is an industrial by-product that originates from the smelting process of nickel and iron-nickel alloys. With the development of the ironnickel industry, the annual discharge amount of ferronickel slag in China exceeds 30 million tons, which has become the fourth largest smelting slag [1]. However, the utilization rate of EFS is less than 10\% [2-4]. Consequently, a large amount of EFS has to be disposed of in landfills and/or sites, which threatens the local ecological environment.

Currently, many investigations have been carried out on the disposal and utilization of EFS in the field of materials preparation, such as geopolymer [5-7], acid-base cement [8,9], concrete aggregate [10,11], cement clinker [8,12], insulation blocks [13], acoustic materials [14], inorganic mineral fibers [15,16], fertilizers [17] and metal recovery [18,19]. Particularly, the utilization of EFS for preparing magnesium cement is one of the most practicable approaches in view of its high-magnesium characteristics.

Phosphate cements, also known as chemically bonded phosphate ceramics, are usually manufactured through the reaction of acidic phosphate and basic metal oxides, forming insoluble phosphate salts as binders. According to the types of metal oxides, phosphate 
cements are commonly divided into zinc phosphate cement (ZPC), magnesium phosphate cement (MPC) [20-22], calcium phosphate cement (CPC) [23,24] and iron phosphate cement (IPC) [25]. Among these, MPC has attracted the most attention and been widely investigated, especially in terms of its thermodynamic characteristics [4,26], influencing factors and mechanical properties [27], formation mechanism [28,29] and applications [30,31]. Its popularity is due to its excellent properties, such as quick setting and high temperature resistance, which can be used as refractory materials [32], filling material for hard tissue [33] and/or concrete repair for road and airport [34]. However, the magnesium oxide used in the MPC system is normally dead-burned at a temperature of $1300-1700{ }^{\circ} \mathrm{C}$, which gives rise to the high energy consumption and production cost. To cut down the cost and green the preparation process, the industrial by-products or solid wastes have been employed as alternative precursors and/or supplementary materials in the preparation of phosphate cement [35-38].

Herein, to further develop the industrial wastes-based MPC, the high-magnesium EFS was used as the substitute for magnesium oxide to react with three kinds of acidic components, including phosphoric acid $\left(\mathrm{H}_{3} \mathrm{PO}_{4}, \mathrm{PA}\right)$, sodium dihydrogen phosphate $\left(\mathrm{NaH}_{2} \mathrm{PO}_{4}, \mathrm{SDP}\right)$ and potassium dihydrogen phosphate $\left(\mathrm{KH}_{2} \mathrm{PO}_{4}, \mathrm{PDP}\right)$. The influence of the phosphorus sources (PS) and raw materials ratio on the compressive strength, early hydration temperature and microstructure of EFS-based magnesium phosphate cement (EMPC) pastes were investigated. Aiming to understand the hydration of EMPC, the hydration product and evolutions of $\mathrm{pH}$ and ions $(\mathrm{Mg}, \mathrm{K}, \mathrm{Na}, \mathrm{P}, \mathrm{Si}$ ) concentrations were analyzed by X-ray diffractometry (XRD), Fourier transform infrared spectroscopy (FTIR), thermos-gravimetric and differential scanning calorimeter (TG/DTG) and inductively coupled plasma-atomic emission spectroscopy (ICP-AES).

\section{Materials and Methods}

\subsection{Raw Materials}

The EFS used in this investigation was kindly supplied by Guangxi Nickel Co., Ltd., in Guangxi, China. The EFS was dried in an oven at $80{ }^{\circ} \mathrm{C}$ for $24 \mathrm{~h}$ and ground for $3 \mathrm{~h}$ in a planetary ball mill (ND7-2L, Nanda Tianzun, Nanjing, China). The particlesize distribution and the chemical composition of EFS powders were measured by Laser diffraction particle size analyzer (master sizer 3000, Malvern Panalytical, Malvern, England) and X-ray fluorescence (XRF, 1800, Shimadzu, Kyoto, Japan) [38], respectively.

Meanwhile, according to our previous investigation, to strengthen the early hydration activity of EFS, a certain amount of pure magnesium oxide $(\mathrm{MgO})$ could be added as the supplementary material in the preparation process [39].

The acidic phosphorus sources used in this study include phosphoric acid $\left(\mathrm{H}_{3} \mathrm{PO}_{4}, \mathrm{PA}\right)$, sodium dihydrogen phosphate $\left(\mathrm{NaH}_{2} \mathrm{PO}_{4}, \mathrm{SDP}\right)$ and potassium dihydrogen phosphate $\left(\mathrm{KH}_{2} \mathrm{PO}_{4}, \mathrm{PDP}\right)$. All the reagents were purchased from Tianjin Fengchuan Chemical Reagent Science and Technology Co., Ltd. (Tianjin, China).

\subsection{Sample Preparation}

Three series of EMPC pastes were prepared and designated as A, B and C by using PA, SDP and PDP as the phosphorus sources, respectively. For each series, the raw material mass ratio was in the range of 3.0-7.0. Meanwhile, a 5\% mass ratio of $\mathrm{MgO}$ was added as the supplementary material for the preparation of the EMPC paste. The mix proportion of EMPC paste is exhibited in Table 1. The preparation of EMPC was performed via the following steps. First, for series $\mathrm{B}$ and $\mathrm{C}$, the dry raw materials including EFS, $\mathrm{MgO}$ and SDP or PDP according to the mix proportion were dry mixed for $5 \mathrm{~min}$. Next, the water was added into the mixtures at the water-to-cement mass ratio of 0.2 and wet mixed for another $5 \mathrm{~min}$. After that, the fresh mixed paste was casted into cube molds with dimensions of $20 \mathrm{~mm} \times 20 \mathrm{~mm} \times 20 \mathrm{~mm}$. Finally, the hardened pastes were demolded after $1 \mathrm{~d}$ and left to cure at room temperature until the pre-set testing time (3, 7 and $28 \mathrm{~d})$. 
Table 1. Mix proportion of EMPC paste and EMPC suspension.

\begin{tabular}{|c|c|c|c|c|c|c|c|}
\hline Series & PS & No. & $\mathrm{EFS} / \mathrm{PS}^{\mathrm{a}}$ & EFS (g) & PS (g) & MgO (g) & $\mathrm{W} / \mathrm{C}^{\mathrm{b}}$ \\
\hline \multirow[t]{5}{*}{ A } & $\mathrm{H}_{3} \mathrm{PO}_{4}$ & A1 & 3.0 & 90.0 & 30.0 & 4.5 & 0.2 \\
\hline & & A2 & 4.0 & 96.0 & 24.0 & 4.8 & 0.2 \\
\hline & & A3 & 5.0 & 100.0 & 20.0 & 4.5 & 0.2 \\
\hline & & A4 & 6.0 & 102.9 & 17.1 & 5.1 & 0.2 \\
\hline & & A5 & 7.0 & 105.0 & 15.0 & 5.3 & 0.2 \\
\hline \multirow[t]{5}{*}{ B } & $\mathrm{NaH}_{2} \mathrm{PO}_{4}$ & B1 & 3.0 & 90.0 & 30.0 & 4.5 & 0.2 \\
\hline & & B2 & 4.0 & 96.0 & 24.0 & 4.8 & 0.2 \\
\hline & & B3 & 5.0 & 100.0 & 20.0 & 4.5 & 0.2 \\
\hline & & B4 & 6.0 & 102.9 & 17.1 & 5.1 & 0.2 \\
\hline & & B5 & 7.0 & 105.0 & 15.0 & 5.3 & 0.2 \\
\hline \multirow[t]{5}{*}{$\mathrm{C}$} & $\mathrm{KH}_{2} \mathrm{PO}_{4}$ & C1 & 3.0 & 90.0 & 30.0 & 4.5 & 0.2 \\
\hline & & $\mathrm{C} 2$ & 4.0 & 96.0 & 24.0 & 4.8 & 0.2 \\
\hline & & C3 & 5.0 & 100.0 & 20.0 & 4.5 & 0.2 \\
\hline & & $\mathrm{C} 4$ & 6.0 & 102.9 & 17.1 & 5.1 & 0.2 \\
\hline & & C5 & 7.0 & 105.0 & 15.0 & 5.3 & 0.2 \\
\hline \multirow[t]{3}{*}{$S$} & $\mathrm{H}_{3} \mathrm{PO}_{4}$ & SA2 & 4.0 & 40.0 & 10.0 & 2.0 & 2.0 \\
\hline & $\mathrm{NaH}_{2} \mathrm{PO}_{4}$ & SB2 & 4.0 & 40.0 & 10.0 & 2.0 & 2.0 \\
\hline & $\mathrm{KH}_{2} \mathrm{PO}_{4}$ & SC2 & 4.0 & 40.0 & 10.0 & 2.0 & 2.0 \\
\hline SC & $\mathrm{KH}_{2} \mathrm{PO}_{4}$ & SCC2 & 4.0 & 40.0 & 10.0 & / & 2.0 \\
\hline
\end{tabular}

Notations: ${ }^{\mathrm{a}}$ mass ratio; ${ }^{\mathrm{b}}$ includes EFS, PS and MgO.

In addition, in order to accurately investigate the hydration behavior, EMPC suspensions (classified as S) with different phosphorus sources were prepared according to the mix proportions listed in Table 1 . The evolution of $\mathrm{pH}$ and ions concentrations was timely monitored. Meanwhile, the control suspension series (named as SC) without the addition of $\mathrm{MgO}$ was also prepared using PDP as the acid source to verify the role of EFS for the provision of $\mathrm{Mg}$ ion.

\subsection{Test Methods and Characterization}

For the EMPC paste, the compressive strength was determined by a compression machine (YAW-100D, Jinan Kesheng, Jinan, China) at 3, 7 and $28 \mathrm{~d}$. All the batch tests were measured on three parallel samples, and the arithmetic means were determined as the final value of compressive strength (GB/T 50081-2019). The crushed samples were collected and dried for the following analysis. The microstructure of EMPC paste was observed by SEM/EDS (Quanta 200 FEG, FEI, Hillsboro, OR, USA). The chemical structure of EFS and EMPC were determined with FTIR (Bruker Ten-sor27, Karlsruhe, German), and the FTIR spectra with a resolution of $4 \mathrm{~cm}^{-1}$ in the range of $4000-400 \mathrm{~cm}^{-1}$ was collected using the $\mathrm{KBr}$ pellet method. The phase compositions of EFS and EMPC were analyzed by an XRD ( $X^{\prime}$ Pert-PRO, Philips, Amsterdam, Netherlands) with a $\mathrm{Cu} \mathrm{K \alpha}$ radiation (1.5406 $\AA$ ) from $10^{\circ}$ to $80^{\circ}$ at a scanning speed of $10^{\circ} / \mathrm{min}$. The thermal stability of EMPC was explored by TG/DTG (STA 2500, Netzsch, Selb, Germany) at a heating rate of $10{ }^{\circ} \mathrm{C} / \mathrm{min}$ in a flowing nitrogen atmosphere [25,40].

For EMPC suspension, the evolution of the $\mathrm{pH}$ of the EMPC suspension was measured with a $\mathrm{pH}$ acidity meter (PHS-3C, INESA, Shanghai, China). For ion ( $\mathrm{Mg}, \mathrm{K}, \mathrm{Na}, \mathrm{P}, \mathrm{Si}$ )concentration measurements, a disposable syringe filter (Zhiyu, Taixing, China) assembled with a $0.22 \mu \mathrm{m}$ filter membrane was used to collect and filter the EMPC suspension $(0.5 \mathrm{~mL})$ at each of the set reaction times. Then, the obtained filtrate was diluted to 20 times and immediately acidified with enough nitric acid solution ( $2 \%$, mass concentration) to prevent the precipitation reaction between $\mathrm{Mg}^{2+}, \mathrm{K}^{+}, \mathrm{Na}^{+}$and $\mathrm{PO}_{4}{ }^{3-}$ before determining the ions concentrations using ICP-AES (Optima 3200 RL, Perkin Elmer, Waltham, MA, USA) [40]. 


\section{Results and Discussion}

\subsection{Physical and Chemical Properties of EFS}

The particle-size distribution of EFS powders is shown in Table 2. The percentage of the particles with a size of less than $48.08 \mu \mathrm{m}$ is about $91 \%$. The chemical composition of EFS is listed in Table 3. The results showed that the EFS contains a large amount of silica, magnesia and iron oxide, accounting for $89.78 \%$ of the total composition. It is worth noting that the amount of $\mathrm{MgO}$ in EFS is up to $23.05 \%$, suggesting a potential resource for the preparation of magnesium phosphate cement. The mineralogical component of EFS is shown in Figure 1. EFS mainly contains crystalline forsterite $\left(\mathrm{Mg}_{2} \mathrm{SiO}_{4}\right)$ phase, as well as a certain amount of amorphous phase.

Table 2. Particle size distribution of EFS powders (wt.\%).

\begin{tabular}{cc}
\hline Particle Size $(\mu \mathrm{m})$ & Percentage (wt. $\%)$ \\
\hline$<6.30$ & 24.10 \\
$6.30 \sim 12.70$ & 28.52 \\
$12.7 \sim 20.69$ & 16.90 \\
$20.69 \sim 48.08$ & 21.56 \\
$48.08 \sim 69.68$ & 5.00 \\
$>69.68$ & 3.92 \\
\hline
\end{tabular}

Table 3. Chemical composition of EFS (wt.\%).

\begin{tabular}{cc}
\hline Compound & Percentage (wt.\%) \\
\hline $\mathrm{SiO}_{2}$ & 55.18 \\
$\mathrm{MgO} \mathrm{F}_{2}$ & 23.05 \\
$\mathrm{Fe}_{2}$ & 11.55 \\
$\mathrm{Al}_{2} \mathrm{O}_{3}$ & 3.37 \\
$\mathrm{CaO}$ & 1.85 \\
$\mathrm{MnO}$ & 1.79 \\
$\mathrm{SO}_{3}$ & 0.37 \\
$\mathrm{~K}_{2} \mathrm{O}$ & 0.05 \\
Others & 2.79 \\
\hline
\end{tabular}

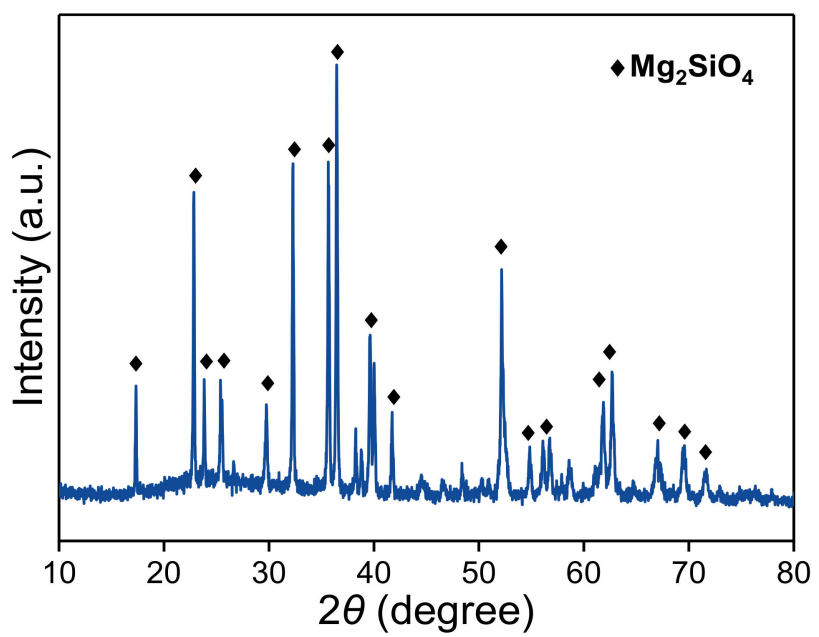

Figure 1. XRD pattern of EFS.

3.2. Mechanical Property and the Evolution of the Hydration Temperature of EMPC Paste 3.2.1. Effect of the Raw Materials Ratio on the Compressive Strength of EMPC Paste

Figure 2 presents the compressive strengths of EMPC pastes with different phosphorus sources and the raw materials ratio at 3, 7 and $28 \mathrm{~d}$. As shown in Figure $2 \mathrm{a}$, the compressive strength first slightly increased and then decreased with the increase in the EFS/PA ratio. 
When the EFS/PA ratio was 4.0, the corresponding compressive strengths of EMPC paste were up to 5.8, 6.0 and 6.3 MPa at 3, 7 and $28 \mathrm{~d}$, respectively. The development of compressive strength of EMPC might be attributed to the reactions between the effective component of EFS or $\mathrm{MgO}$ and PA to form the hydration products, whereas the inert component of EFS acted as the aggregate in the cementitious system. When the EFS/PA was below 4.0, excess unreacted PA in the cementitious system led to a decrease in compressive strength. At a higher EFS/PA ratio, the amount of EFS apparently increased, while the formation amount of hydration products decreased due to the limited amount of PA, thus resulting in a subsequent decrease in compressive strength.
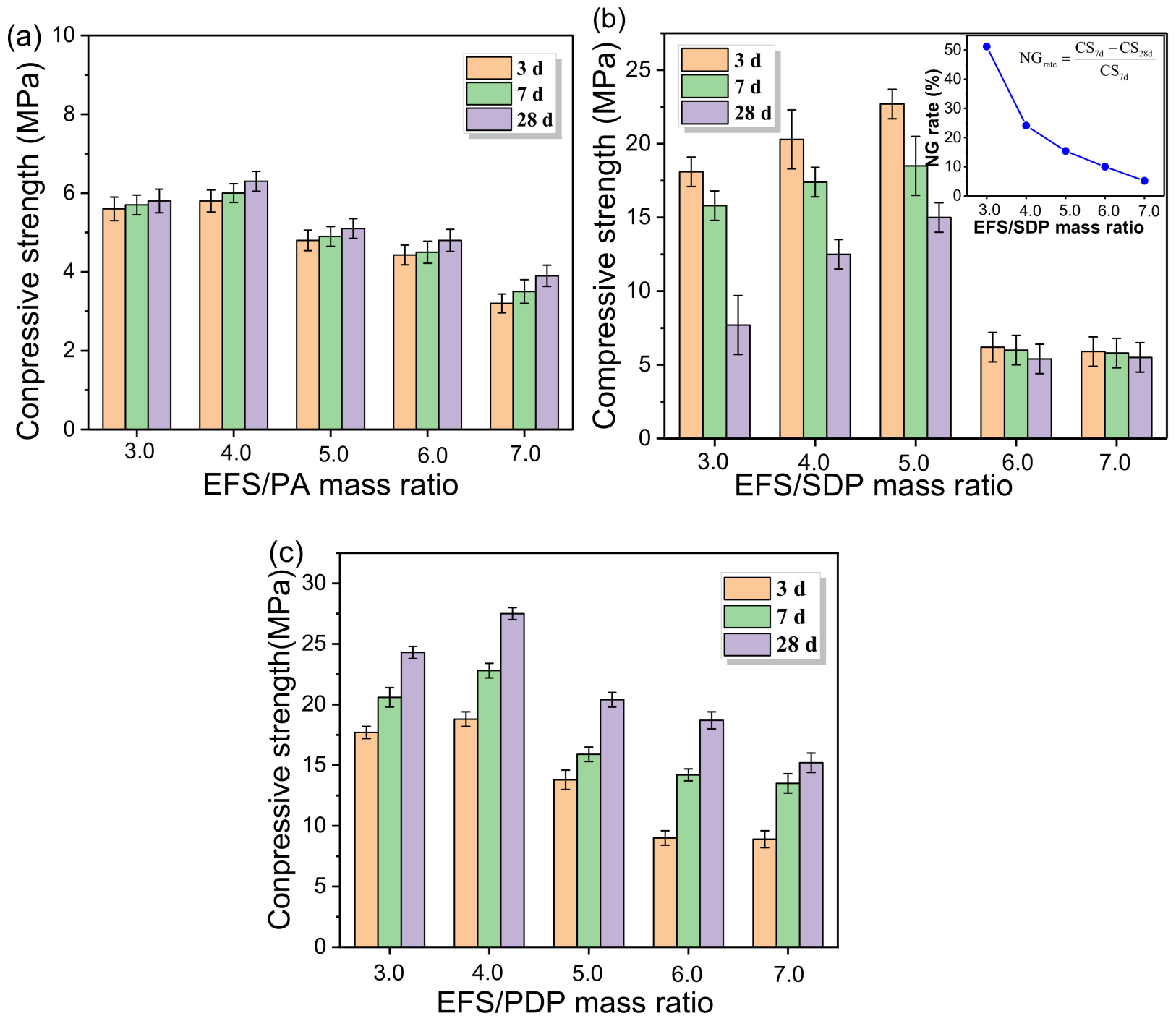

Figure 2. Compressive strengths of EMPC prepared with different EFS/PS ratios hydrated for 3, 7, 28 d. (a) EFS- $\mathrm{H}_{3} \mathrm{PO}_{4}$ system, (b) EFS-NaH $\mathrm{NO}_{4}$ system and the negative growth rate (NG rate) of compressive strength with different EFS/SDP ratios at ages from 7 to $28 \mathrm{~d}$, (c) $\mathrm{EFS}-\mathrm{KH}_{2} \mathrm{PO}_{4}$ system.

The effect of the EFS/SDP ratio on the compressive strength of EMPC pastes is shown in Figure 2b. As the EFS/SDP ratio increased, the compressive strength first increased and then decreased. When the EFS/SDP ratio was up to 5.0, the compressive strength reached up to $22.7,18.5$ and $15 \mathrm{MPa}$ at 3, 7 and $28 \mathrm{~d}$, respectively. Unfortunately, the compressive strength gradually decreased as the curing time increased from 3 to $28 \mathrm{~d}$. This is known as the negative growth of compressive strength, which is associated with the hygroscopic cracking caused by the hygroscopicity of the surplus SDP in the system. Additionally, the negative growth rates of the compressive strength (NG rate) from 7 to $28 \mathrm{~d}$ were 51.2\%, 
$24.1 \%, 15.4 \%, 10 \%$ and $5.2 \%$ at the EFS/SDP ratio of 3.0, 4.0, 5.0, 6.0, 7.0, respectively, which was in perfect accordance with the reduction in SDP in the EMPC (Table 1). The surplus SDP in the EMPC system would result in hygroscopic expansion, and the higher the amount of SDP in the EMPC, the more obvious the decline in compressive strength.

The effect of the EFS/PDP ratio on the compressive strength of EMPC pastes is shown in Figure 2c. It can be observed that the change trend of the compressive strength is similar to that of the series A. The compressive strength at 3, 7 and $28 \mathrm{~d}$ reached up to 18.8, 22.8 and $27.5 \mathrm{MPa}$ at the EFS/PDP ratio of 4.0, respectively, which showed a significant increase in comparison to series $\mathrm{A}$ and $\mathrm{B}$.

On the basis of the above experimental data, it can be found that the compressive strength of EMPC is significantly impacted by the phosphorus sources (PA, SDP and PDP) and EFS/PS ratio. For series $\mathrm{A}$ (EFS- $\mathrm{H}_{3} \mathrm{PO}_{4}$ system), the highest compressive strength was obtained at the EFS/PA ratio of 4.0, corresponding to 5.8, 6.0 and $6.3 \mathrm{MPa}$ at 3, 7 and $28 \mathrm{~d}$, respectively. Furthermore, when PDP is employed as PS, the best compressive strength reaches up to $18.8,22.8$ and $27.5 \mathrm{MPa}$ at 3, 7 and $28 \mathrm{~d}$, respectively, while SDP used as PS exerts varying influences on the compressive strength, and presents a negative growth as the curing age prolonged in the later hydration process.

\subsubsection{Early Hydration Temperature Analysis of EMPC Paste}

The early hydration temperature of EMPC with optimal proportions (EFS/PA $=4.0$ $\mathrm{EFS} / \mathrm{SDP}=5.0$, EFS $/ \mathrm{PDP}=4.0)$ in the initial period $(0-70 \mathrm{~min})$ is shown in Figure 3 . As displayed in Figure 3, the hydration of EMPC was an exothermic process, and the peaks of the hydration temperature were $74,36,32{ }^{\circ} \mathrm{C}$ in the EFS- $\mathrm{H}_{3} \mathrm{PO}_{4}, \mathrm{EFS}-\mathrm{NaH}_{2} \mathrm{PO}_{4}$ and EFS- $\mathrm{KH}_{2} \mathrm{PO}_{4}$ systems, respectively. It is apparent that the temperature curve of $\mathrm{EFS}-\mathrm{H}_{3} \mathrm{PO}_{4}$ system was obviously different from the others, and the hydration temperature sharply rose to $74{ }^{\circ} \mathrm{C}$ within the first minute and then slowly dropped to room temperature after hydration for $70 \mathrm{~min}$. This indicates that the reaction rate between EFS and $\mathrm{H}_{3} \mathrm{PO}_{4}$ was extremely high, whereas a high reaction rate would lead to structural defects (such as pores and cracks) of the paste, thereby causing a reduction in the compressive strength. In comparison, the acid-base reactions in both the EFS- $\mathrm{NaH}_{2} \mathrm{PO}_{4}$ and EFS- $\mathrm{KH}_{2} \mathrm{PO}_{4}$ systems are more moderate.

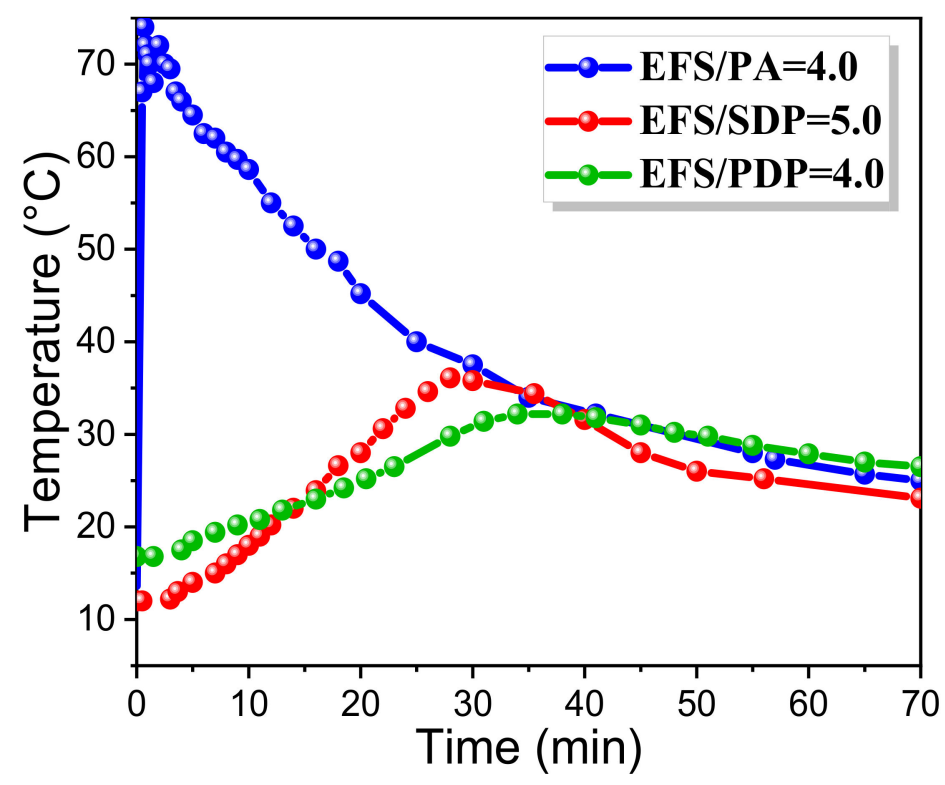

Figure 3. Early hydration temperature curves of EMPC with optimal proportions (A2: EFS/PA = 4.0, $\mathrm{B} 3: \mathrm{EFS} / \mathrm{SDP}=5.0, \mathrm{C} 2: \mathrm{EFS} / \mathrm{PDP}=4.0)$. 


\subsection{Characterization of EMPC Pastes}

\subsubsection{Mineralogical Composition Analysis}

The XRD patterns of EMPC pastes $(\mathrm{A} 2: \mathrm{EFS} / \mathrm{PA}=4.0, \mathrm{~B} 3: \mathrm{EFS} / \mathrm{SDP}=5.0$ and $\mathrm{C} 1-$ C5: EFS/PDP ratios of 3.0, 4.0, 5.0, 6.0, 7.0) at $28 \mathrm{~d}$ are shown in Figure 4. As shown in Figure $4 \mathrm{a}$, a certain amount of magnesium phosphate $\left(\mathrm{Mg}_{3}\left(\mathrm{PO}_{4}\right)_{2} \cdot 22 \mathrm{H}_{2} \mathrm{O}\right)$ was formed as the hydration product in three EMPC systems. The intensity of $\mathrm{Mg}_{3}\left(\mathrm{PO}_{4}\right)_{2} \cdot 22 \mathrm{H}_{2} \mathrm{O}$ characteristics peaks in the $\mathrm{A} 2$ sample (EFS- $\mathrm{H}_{3} \mathrm{PO}_{4}$ system) was obviously stronger than that of sample B3 (EFS-NaH $\mathrm{PO}_{4}$ system) and $\mathrm{C} 2\left(\mathrm{EFS}-\mathrm{KH}_{2} \mathrm{PO}_{4}\right.$ system), indicating that $\mathrm{Mg}_{3} \mathrm{PO}_{4} \cdot 22 \mathrm{H}_{2} \mathrm{O}$ was the main hydration product in series A. For series $\mathrm{C}$, apart from $\mathrm{Mg}_{3} \mathrm{PO}_{4} \cdot 22 \mathrm{H}_{2} \mathrm{O}$, an abundant of $\mathrm{K}$-struvite $\left(\mathrm{KMgPO}_{4} \cdot 6 \mathrm{H}_{2} \mathrm{O}\right)$ was also formed, and the amount of K-struvite increased with the decrease in the EFS/PDP mass ratio (Figure $4 b$ ). It manifests that more of the hydration product of $\mathrm{KMgPO}_{4} \cdot 6 \mathrm{H}_{2} \mathrm{O}$ was formed as the cementitious phase in the sample $\mathrm{C} 2$ to strengthen the mechanical strength, which was in accordance with the results in Figure 2c. However, aside from a trace of $\mathrm{Mg}_{3}\left(\mathrm{PO}_{4}\right)_{2} \cdot 22 \mathrm{H}_{2} \mathrm{O}$, no other crystalline hydration product was formed in the sample B3. According to the information the reference reported, amorphous phase-like $\mathrm{NaMgPO}_{4} \cdot 6 \mathrm{H}_{2} \mathrm{O}$ may be formed in series $\mathrm{B}$ [41]. Notably, the characteristic peaks of magnesium silicate $\left(\mathrm{Mg}_{2} \mathrm{SiO}_{4}\right)$ and magnesium oxide $(\mathrm{MgO})$ were detected for three series EMPC pastes, indicating that a part of the raw materials remained unreacted.
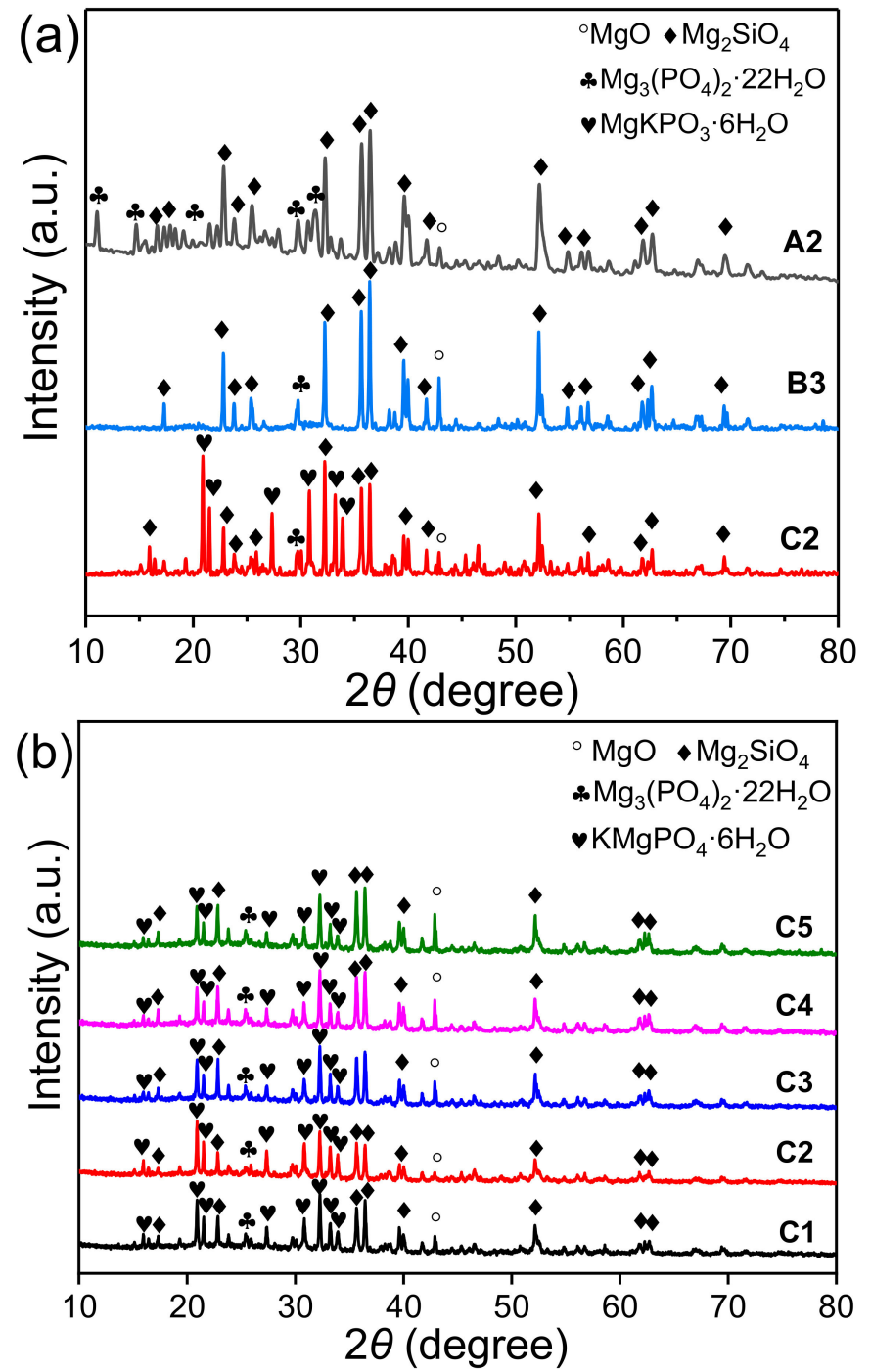

Figure 4. XRD patterns of EMPC pastes hydrated for $28 \mathrm{~d}$ : (a) A2: $\mathrm{EFS} / \mathrm{PA}=4.0, \mathrm{~B} 3$ : $\mathrm{EFS} / \mathrm{SDP}=5.0$ and C2: $\mathrm{EFS} / \mathrm{PDP}=4.0$, (b) C1-C5: EFS/PDP ratios of 3.0, 4.0, 5.0, 6.0, 7.0. 


\subsubsection{SEM Analysis of EMPC Paste}

The influence of phosphorus sources on the microstructure of EMPC pastes is shown in Figure 5. As shown in Figure 5a, a large number of pores and cracks were presented on the fracture surface of EMPC paste (A2) with EFS/PA $=4.0$ at $28 \mathrm{~d}$ resulting in a low compressive strength, which was in agreement with the results of Figures 3 and 2a. It may be attributable to the reaction between EFS and $\mathrm{H}_{3} \mathrm{PO}_{4}$ releasing more heat to cause the water evaporation to further form additional defects in the EMPC paste. In the EFS- $\mathrm{NaH}_{2} \mathrm{PO}_{4}$ system (Figure 5b, EFS/SDP = 5.0, B3), it can also be observed that a lot of cracks presented in the EMPC paste, which may provide the opportunity for the air and water to access the inside of the paste, causing the moisture adsorption of unreacted SDP, thereby leading to the decrease in compressive strength. The SEM images of the EFS- $\mathrm{KH}_{2} \mathrm{PO}_{4}$ systems (EFS/PDP $=4.0,5.0,6.0,7.0$ ) are shown in Figure $5 \mathrm{c}-\mathrm{g}$. The compactness and hydration products of pastes strongly depended on the EFS/PDP ratio. As the EFS/PDP ratio increased, the proportion of the binder and aggregate decreased. At $\mathrm{EFS} / \mathrm{PDP}=4.0$, a number of rod-like crystals were formed, suggested to be the K-struvite by the EDS analysis. Thus, the hydrated EMPC paste prepared with PDP seemed compact and cohesive, contributing to the high compressive strength (Figure 2c).

\subsubsection{FTIR Analysis}

Figure 6 displays the FTIR spectra of A2, $\mathrm{B} 3$ and $\mathrm{C} 1-\mathrm{C} 5$ pastes hydrated for $28 \mathrm{~d}$. With regard to $\mathrm{Mg}_{3}\left(\mathrm{PO}_{4}\right)_{2} \cdot 22 \mathrm{H}_{2} \mathrm{O}$ and $\mathrm{KMgPO}_{4} \cdot 6 \mathrm{H}_{2} \mathrm{O}$ or $\mathrm{NaMgPO}_{4} \cdot 6 \mathrm{H}_{2} \mathrm{O}$, the absorbance bands at 1014 and $572 \mathrm{~cm}^{-1}$ were assigned to the $\mathrm{PO}_{4}{ }^{3-}$ antisymmetric stretching and the $\mathrm{P}-\mathrm{O}$ bending vibrations, respectively [42,43]. The bands at 897 and $611 \mathrm{~cm}^{-1}$ were assigned to $\mathrm{SiO}_{4}$ stretching $\left(800-1100 \mathrm{~cm}^{-1}\right)$ and bending $\left(650-500 \mathrm{~cm}^{-1}\right)$ vibrations, respectively. The band located at $1682-1600 \mathrm{~cm}^{-1}$ was attributed to the bending vibrations of the $\mathrm{H}_{2} \mathrm{O}$ molecules. The broad band in the $3800-2200 \mathrm{~cm}^{-1}$ region was assigned to the $\mathrm{O}-\mathrm{H}$ stretching vibration. According to the references [40,44-46], the broad band at $3510 \mathrm{~cm}^{-1}$ in the sample $\mathrm{A} 2$ and $\mathrm{B} 3$ was assigned to the $\mathrm{OH}$ stretching vibration of the crystalline water, whereas it shifted to the low frequency $\left(2950,2350 \mathrm{~cm}^{-1}\right)$ with the existence of fairly strong hydrogen bonds in the structure of $\mathrm{KMgPO}_{4} \cdot 6 \mathrm{H}_{2} \mathrm{O}$ or $\mathrm{NaMgPO}_{4} \cdot 6 \mathrm{H}_{2} \mathrm{O}$.

\subsubsection{TG/DTG Analysis}

Figure 7 shows the TG/DTG curves of sample A2, B3 and C2 hydrated for $28 \mathrm{~d}$. It is apparent that the weight-loss of EMPC pastes with different phosphorus sources between 90 and $130{ }^{\circ} \mathrm{C}$ presented a great gap. The largest weight loss was as high as $10.02 \%$ in the sample A2, attributed to the thermal decomposition of $\mathrm{Mg}_{3} \mathrm{PO}_{4} \cdot 22 \mathrm{H}_{2} \mathrm{O}$. The weight loss related to the decomposition of $\mathrm{MgKPO}_{4} \cdot 6 \mathrm{H}_{2} \mathrm{O}$ in the sample $\mathrm{C} 2$ was up to $7.28 \%$. Although the bound water in the $\mathrm{Mg}_{3} \mathrm{PO}_{4} \cdot 22 \mathrm{H}_{2} \mathrm{O}(70.3 \%)$ was higher than that of $\mathrm{MgKPO}_{4} \cdot 6 \mathrm{H}_{2} \mathrm{O}(40.6 \%)$, the weight-loss rate was obviously inferior to the theoretical ratio of 1.73. It suggests that more $\mathrm{MgKPO}_{4} \cdot 6 \mathrm{H}_{2} \mathrm{O}$ was formed in sample $\mathrm{C} 2$, which was in agreement with the XRD results, as given in Figure 4. In the sample B3, the weight loss at around $90^{\circ} \mathrm{C}$ was as low as $2.31 \%$, indicating that less of the hydration product was formed. The similar decomposition curves in both sample $\mathrm{B} 3$ and $\mathrm{C} 2$, suggested that amorphous $\mathrm{NaMgPO}_{4} \cdot 6 \mathrm{H}_{2} \mathrm{O}$ may be responsible for the weight loss in the EFS- $\mathrm{NaH}_{2} \mathrm{PO}_{4}$ system [40].

\subsection{Evolutions of $\mathrm{pH}$ and Ions Concentrations in EMPC Suspension}

To further reveal the hydration pathway of EMPC, the changes of $\mathrm{pH}$ and ions (i.e., $\mathrm{Mg}, \mathrm{P}, \mathrm{Si}, \mathrm{Na}$ and $\mathrm{K}$ ) concentrations in the EMPC suspensions (SA2, SB2, SC2 and control group of SCC2) were investigated, and the results are shown in Figure 8. 

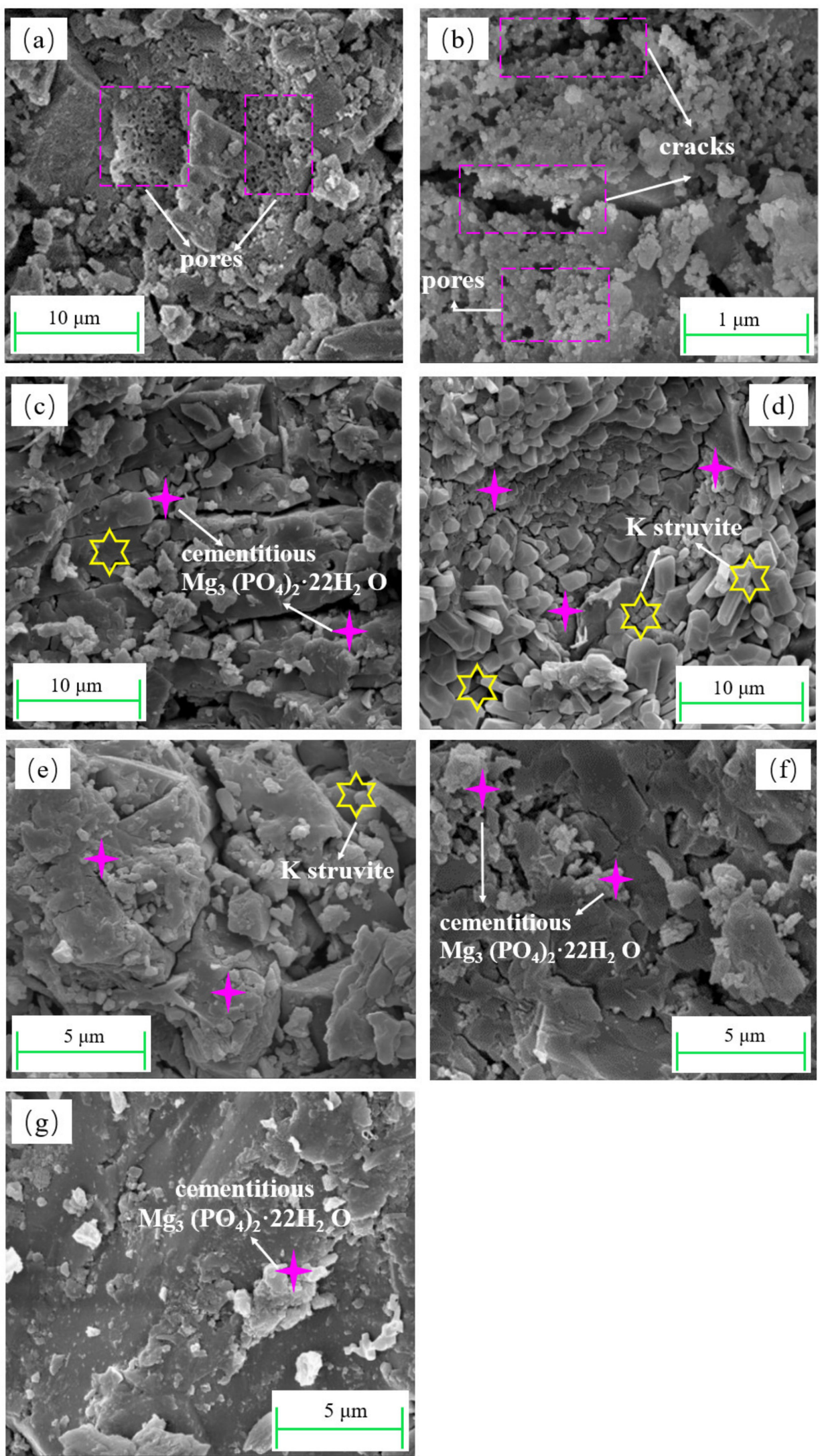

Figure 5. SEM images of EMPC pastes with different phosphorus sources hydrated for $28 \mathrm{~d}$ : (a) $\mathrm{A} 2: \mathrm{EFS} / \mathrm{PA}=4.0$, (b) $\mathrm{B} 3: \mathrm{EFS} / \mathrm{SDP}=5.0$, (c) $\mathrm{C} 1: \mathrm{EFS} / \mathrm{PDP}=3.0$, (d) $\mathrm{C} 2: \mathrm{EFS} / \mathrm{PDP}=4.0$, (e) $\mathrm{C} 3: \mathrm{EFS} / \mathrm{PDP}=5.0$, (f) $\mathrm{C} 4: \mathrm{EFS} / \mathrm{PDP}=6.0,(\mathrm{~g}) \mathrm{C} 5: \mathrm{EFS} / \mathrm{PDP}=7.0$. 


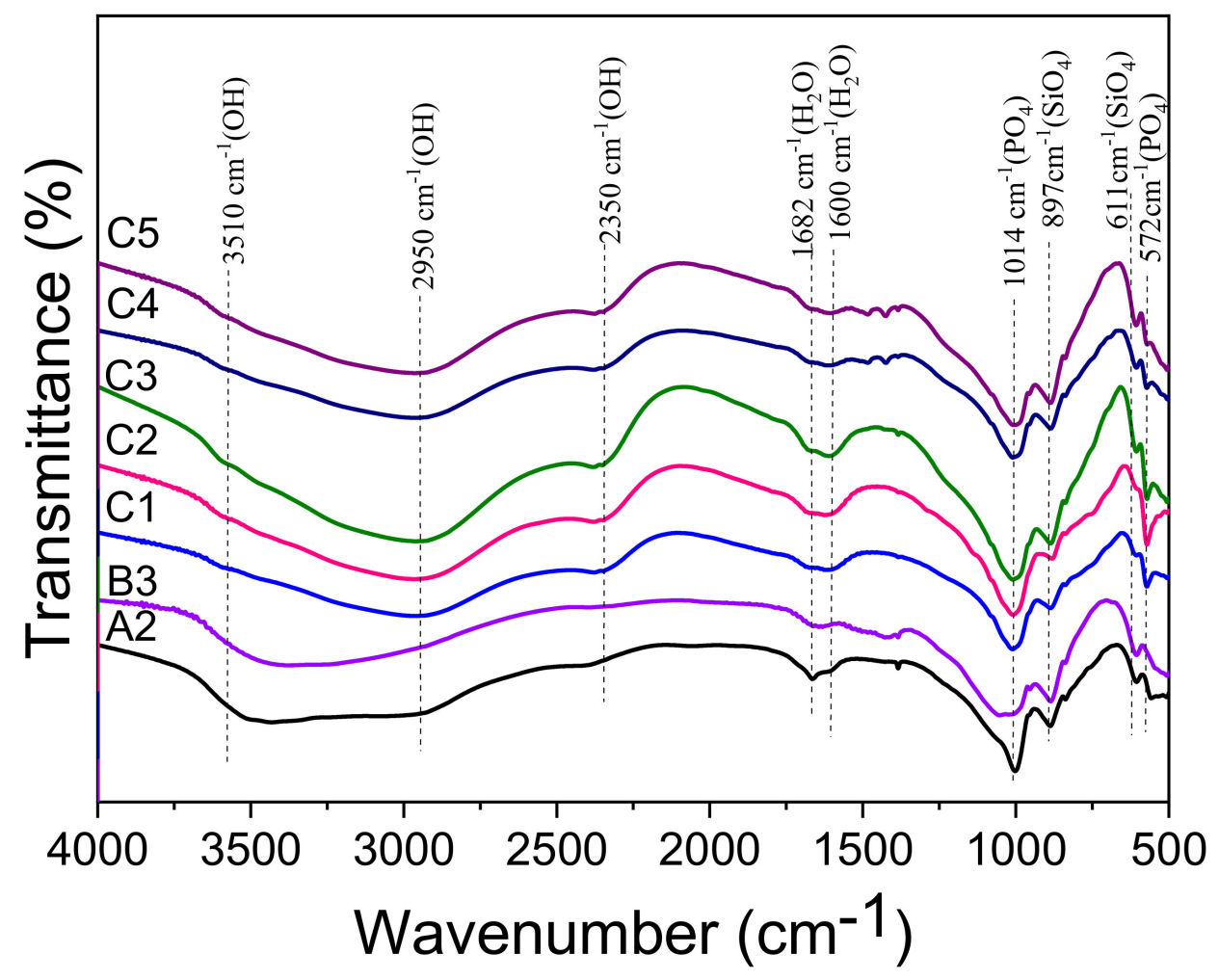

Figure 6. FTIR spectra of A2, B3 and series C (C1-C5) pastes hydrated for $28 \mathrm{~d}$.

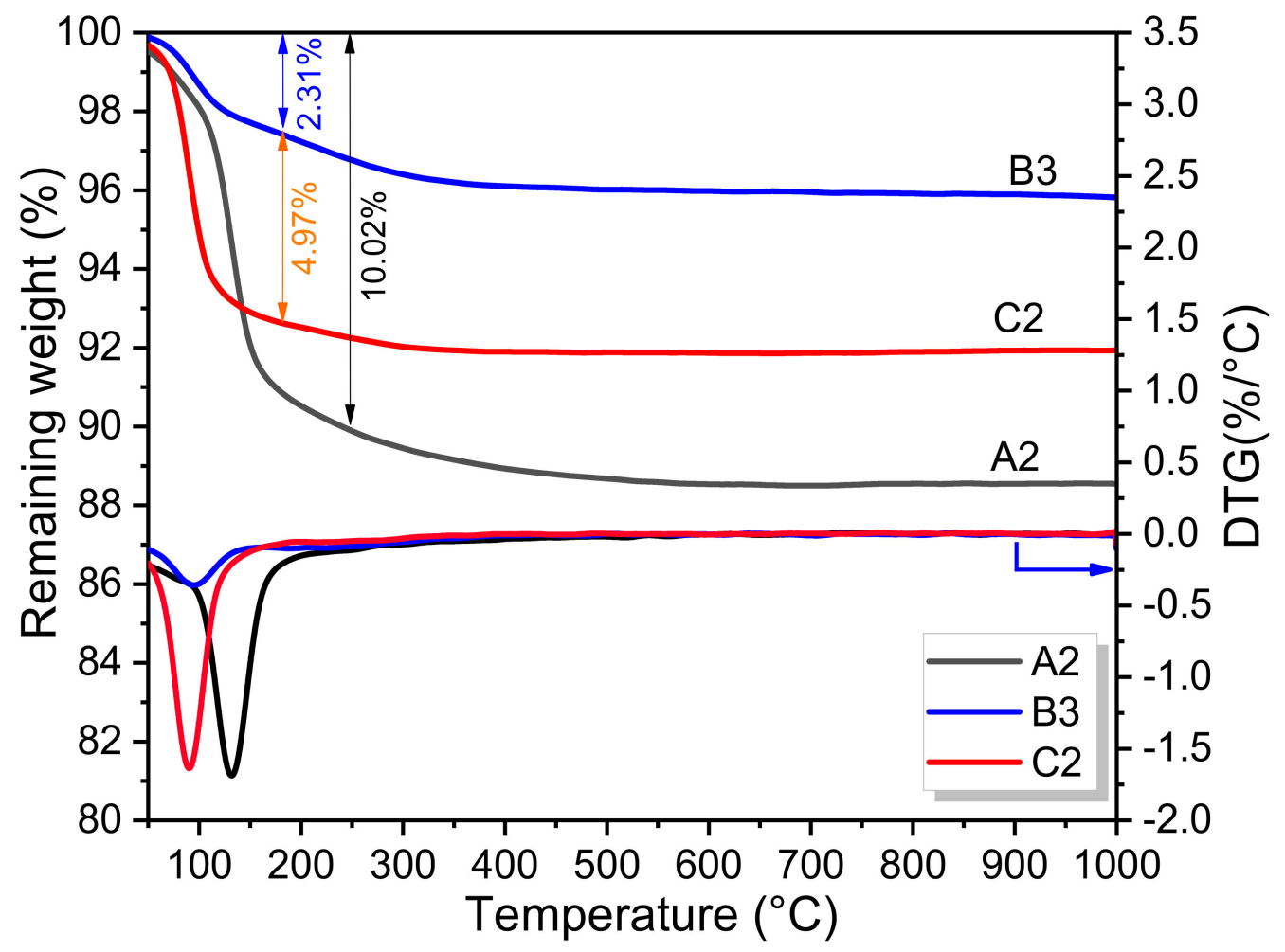

Figure 7. TG/DTG curves of sample A2, B3 and C2. 

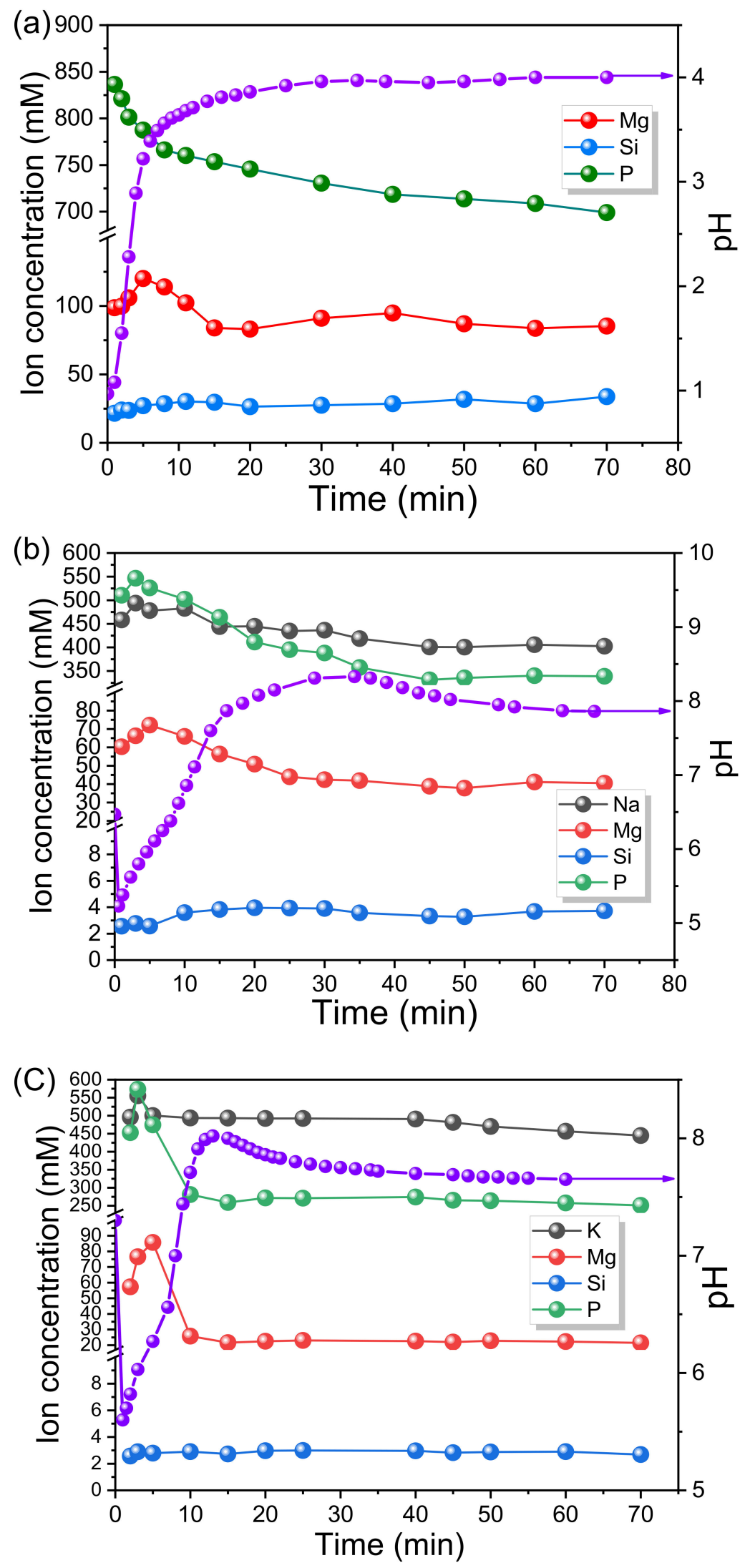

Figure 8. Cont. 


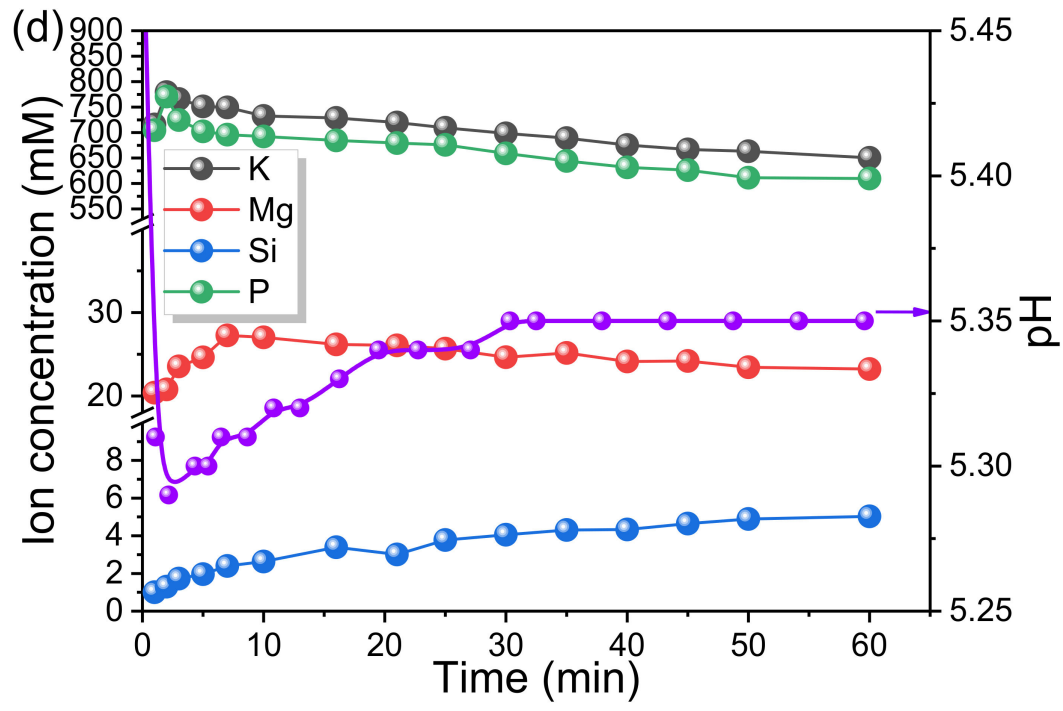

Figure 8. The evolution of ions concentration and $\mathrm{pH}$ value in the EMPC suspensions: (a) SA2: $\mathrm{EFS} / \mathrm{PA}=4.0$; (b) SB2: $\mathrm{EFS} / \mathrm{SDP}=4.0$; (c) SC2: $\mathrm{EFS} / \mathrm{PDP}=4.0$; (d) SCC2: EFS $/ \mathrm{PDP}=4.0$ without $\mathrm{MgO}$.

As shown in Figure 8a, the $\mathrm{pH}$ value of SA2 sharply increased at the initial stage and then slowly increased to a final steady state at around $4.0(70 \mathrm{~min})$. While the evolutions for $\mathrm{Si}, \mathrm{P}$ and $\mathrm{Mg}$ concentrations were quite different, the Si concentrations continued to rise throughout, confirming the continual dissolution of $\mathrm{Mg}_{2}\left(\mathrm{SiO}_{4}\right)$ from EFS. For the P and $\mathrm{Mg}$ concentrations, at the initial stage (within $5 \mathrm{~min}$ ), they presented an opposite trend, suggesting only few amount of hydrates were formed. Additionally, the release rate of $\mathrm{Mg}$ from $\mathrm{MgO}$ and/or EFS was faster than the consummation rate of $\mathrm{Mg}$, which reflected an overall increase in $\mathrm{Mg}$ and a decrease in $\mathrm{P}$ concentrations. After $5 \mathrm{~min}$, the $\mathrm{Mg}$ concentration started to decrease quickly, indicating the fast precipitation of hydrates, until it became constant after $30 \mathrm{~min}$. As displayed by Figure 4 , the hydration product $\mathrm{Mg}_{3} \mathrm{PO}_{4} \cdot 22 \mathrm{H}_{2} \mathrm{O}$ was formed in sample A2. As shown in Figure 8b,c, a similar trend was observed in both SB2 and SC2. Apart from the Si concentration, all the ions concentrations including Na (or $\mathrm{K}), \mathrm{P}, \mathrm{Mg}$ first increased and then decreased. At the first stage (within $5 \mathrm{~min}$ ), the increase in concentrations was attributed to the dissolution of SDP, PDP, MgO and EFS. According to the change of $\mathrm{pH}$, it can be inferred that the SDP and PDP was dissolved firstly, resulting a sharp decrease in $\mathrm{pH}$ ( $\mathrm{pH}$ as low as 5.2 and 5.6, respectively). Then, the increase in $\mathrm{pH}$ occurred due to the dissolution of $\mathrm{MgO}$ and $\mathrm{EFS}$ reacting with $\mathrm{H}^{+}(\mathrm{pH}$ as high as 8.0 and 8.3, respectively). Between 5 and $20 \mathrm{~min}$, the apparent changes in $\mathrm{Na}$ (or K), $\mathrm{P}$ and $\mathrm{Mg}$ concentrations were attributed to the main precipitation reaction of hydrates, which formed crystalline $\mathrm{KMgPO}_{4} \cdot 6 \mathrm{H}_{2} \mathrm{O}$ or amorphous $\mathrm{NaMgPO}_{4} \cdot 6 \mathrm{H}_{2} \mathrm{O}$ [47]. However, it is worth noting that the variation degree of $\mathrm{Mg}$, P and K in SC2 $(59.87,303.19,108.7 \mathrm{mM})$ was higher than that of SB2 $(28.14,210.1,84.47 \mathrm{mM})$, indicating that more precipitates were formed in SC2. In addition, the result of the control experiment for SCC2 without $\mathrm{MgO}$ is shown in Figure $8 \mathrm{~d}$. It can be observed that a certain amount of $\mathrm{Mg}$ was released from EFS, which indicated that the hydrates $\mathrm{KMgPO}_{4} \cdot 6 \mathrm{H}_{2} \mathrm{O}$ could be also formed through the acid-base reaction between EFS and $\mathrm{KH}_{2} \mathrm{PO}_{4}$.

\subsection{Discussion of the Hydration Mechanism of EMPC}

On the basis of the above mentioned experimental and characterization results, the hydration pathway of EMPC can be concluded via the following three steps. The formation mechanism of the EMPC paste is schematically described in Figure 9. 


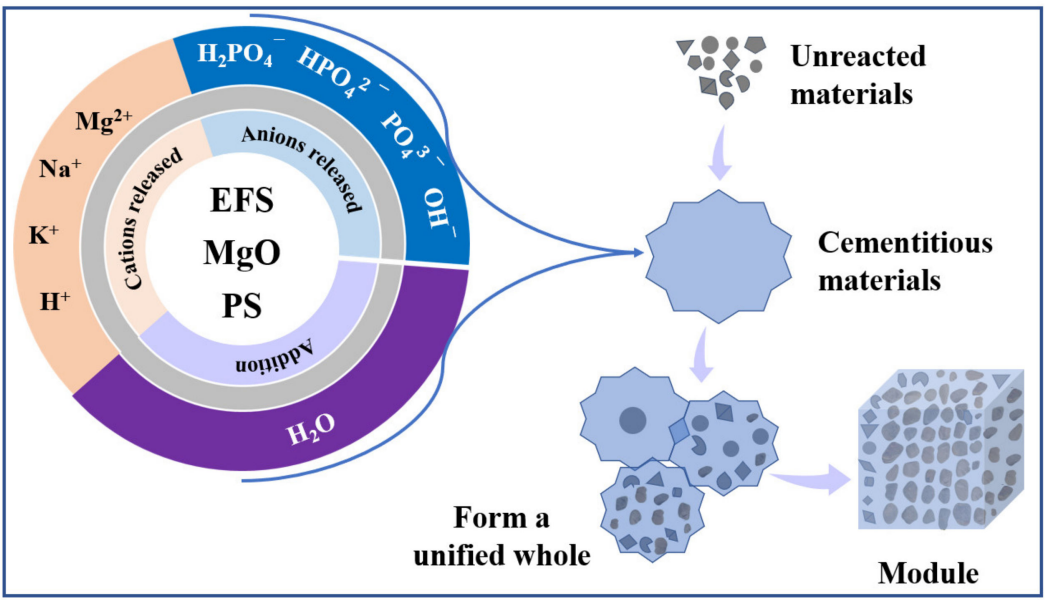

Figure 9. Scheme of formation mechanism of the EMPC.

(1) The dissolution of acidic phosphorus sources $\left(\mathrm{H}_{3} \mathrm{PO}_{4}, \mathrm{NaH}_{2} \mathrm{PO}_{4}, \mathrm{KH}_{2} \mathrm{PO}_{4}\right)$ releases the $\mathrm{H}^{+}, \mathrm{H}_{2} \mathrm{PO}_{4}{ }^{-}, \mathrm{HPO}_{4}{ }^{2-}, \mathrm{PO}_{4}{ }^{3-}, \mathrm{Na}^{+}$or $\mathrm{K}^{+}$, which can be described as Equations (1)-(6).

$$
\begin{gathered}
\mathrm{H}_{3} \mathrm{PO}_{4} \rightleftharpoons \mathrm{H}_{2} \mathrm{PO}_{4}{ }^{-}+\mathrm{H}^{+} \\
\mathrm{H}_{2} \mathrm{PO}_{4}{ }^{-} \rightleftharpoons \mathrm{HPO}_{4}{ }^{2-}+\mathrm{H}^{+} \\
\mathrm{HPO}_{4}{ }^{2-} \rightleftharpoons \mathrm{PO}_{4}{ }^{3-}+\mathrm{H}^{+} \\
\mathrm{MeH}_{2} \mathrm{PO}_{4} \rightarrow \mathrm{H}_{2} \mathrm{PO}_{4}{ }^{-}+\mathrm{Me}^{+}(\mathrm{Me}=\mathrm{Na} \text { or } \mathrm{K}) \\
\mathrm{H}_{2} \mathrm{PO}_{4}{ }^{-} \rightleftharpoons \mathrm{HPO}_{4}{ }^{2-}+\mathrm{H}^{+} \\
\mathrm{HPO}_{4}{ }^{2-} \rightleftharpoons \mathrm{PO}_{4}{ }^{3-}+\mathrm{H}^{+}
\end{gathered}
$$

(2) $\mathrm{MgO}$ or $\mathrm{Mg}_{2} \mathrm{SiO}_{4}$ contained in EFS dissolves in the above-acidic solution ( $\mathrm{pH}=1.0$, 5.2, 5.6 for EFS- $\mathrm{H}_{3} \mathrm{PO}_{4}, \mathrm{EFS}-\mathrm{NaH}_{2} \mathrm{PO}_{4}, \mathrm{EFS}-\mathrm{KH}_{2} \mathrm{PO}_{4}$ system, respectively) to release the $\mathrm{Mg}^{2+}$ (Equations (7) and (8)). The dissolution rate of $\mathrm{Mg}_{2} \mathrm{SiO}_{4}$ is slower than $\mathrm{MgO}$, leading that the decrease of $\mathrm{Mg}$ is in different degree with the later acid-base reaction [39].

$$
\begin{gathered}
\mathrm{MgO}+\mathrm{H}^{+} \rightarrow \mathrm{Mg}^{2+}+\mathrm{OH}^{-} \\
\mathrm{Mg}_{2} \mathrm{SiO}_{4}+4 \mathrm{H}^{+} \rightarrow 2 \mathrm{Mg}^{2+}+\mathrm{Si}(\mathrm{OH})_{4}
\end{gathered}
$$

(3) The precipitation reaction occurs between the acid phosphate and pre-released cations (Equations (9) and (10)), for which $\mathrm{Mg}_{3} \mathrm{PO}_{4} \cdot 22 \mathrm{H}_{2} \mathrm{O}, \mathrm{KMgPO}_{4} \cdot 6 \mathrm{H}_{2} \mathrm{O}, \mathrm{NaMgPO}_{4} \cdot 6 \mathrm{H}_{2} \mathrm{O}$ are formed principally as binders to secure the unreacted $\mathrm{Mg}_{2} \mathrm{SiO}_{4}$ or other materials contained in the EFS, and finally build a hardened paste with a high compressive strength [48].

$$
\begin{gathered}
3 \mathrm{Mg}^{2+}+2 \mathrm{H}_{2} \mathrm{PO}_{4}^{-}+4 \mathrm{OH}^{-}+18 \mathrm{H}_{2} \mathrm{O} \rightarrow \mathrm{Mg}_{3}\left(\mathrm{PO}_{4}\right)_{2} \cdot 22 \mathrm{H}_{2} \mathrm{O} \\
\mathrm{Mg}^{2+}+\mathrm{K}^{+}+\mathrm{H}_{2} \mathrm{PO}_{4}{ }^{-}+6 \mathrm{H}_{2} \mathrm{O} \rightarrow \mathrm{KMgPO}_{4} \cdot 6 \mathrm{H}_{2} \mathrm{O}
\end{gathered}
$$

\section{Conclusions}

The preparation of magnesium phosphate cement using high-magnesium EFS is one of the most practicable approaches. In this study, three species of phosphorus sources were adopted as the acidic component to react with the EFS when preparing EFS-based magnesium phosphate cement (EMPC). The effect of raw materials' mass ratio on the mechanical strength, early hydration temperature and microstructure of EMPC paste were systematically investigated. The highest compressive strength of EMPC paste is 6.3, 22.7 and 27.5 MPa when hydrated for $28 \mathrm{~d}$ at the EFS/PA = 4.0, EFS/SDP = 5.0 and $\mathrm{EFS} / \mathrm{PDP}=4.0$, respectively. The XRD, FTIR and TG/DTG results verified the develop- 
ment of EMPC mainly due to the formation of hydration products, i.e., $\mathrm{Mg}_{3} \mathrm{PO}_{4} \cdot 22 \mathrm{H}_{2} \mathrm{O}$, $\mathrm{KMgPO}_{4} \cdot 6 \mathrm{H}_{2} \mathrm{O}, \mathrm{NaMgPO}_{4} \cdot 6 \mathrm{H}_{2} \mathrm{O}$ as the binders to connect the unreacted EFS contributing to a high compressive strength. However, the hydration of EMPC is a multi-stage process, including the dissolution of $\mathrm{PS}, \mathrm{MgO}$ and $\mathrm{Mg}_{2} \mathrm{SiO}_{4}$, and precipitation reaction when forming $\mathrm{K} / \mathrm{Na}$-struvite and $\mathrm{Mg}_{3} \mathrm{PO}_{4} \cdot 22 \mathrm{H}_{2} \mathrm{O}$ binders.

Author Contributions: C.Y.: Conceptualization, Methodology, Writing -original draft preparation. H.M.: Conceptualization, Methodology, data curation. Z.L.: Methodology, Supervision, Writingreview and editing. X.Z.: Methodology, Supervision, Writing-review and editing. L.W.: Conceptualization, Methodology, Data curation. All authors have read and agreed to the published version of the manuscript.

Funding: The authors appreciate the financial support from the National Natural Science Foundation of China (No. 21866018), Yunnan Ten Thousand Talents Plan Young \& Elite Talents Project (No. YNWR-QNBJ-2018-388 and YNWR-QNBJ-2020-063).

Institutional Review Board Statement: Not applicable.

Informed Consent Statement: Not applicable.

Data Availability Statement: Not applicable.

Conflicts of Interest: The authors declare no conflict of interest.

\section{References}

1. Xi, B.; Li, R.; Zhao, X.; Dang, Q.; Zhang, D.; Tan, W. Constraints and opportunities for the recycling of growing ferronickel slag in China. Resour. Conserv. Recycl. 2018, 139, 15-16. [CrossRef]

2. Peng, Z.; Gu, F.; Zhang, Y.; Tang, H.; Ye, L.; Tian, W.; Liang, G.; Rao, M.; Li, G.; Jiang, T. Chromium: A Double-Edged Sword in Preparation of Refractory Materials from Ferronickel Slag. ACS Sustain. Chem. Eng. 2018, 8, 10536-10544. [CrossRef]

3. Bian, Z.; Jin, G.; Ji, T. Effect of combined activator of $\mathrm{Ca}(\mathrm{OH})_{2}$ and $\mathrm{Na}_{2} \mathrm{CO}_{3}$ on workability and compressive strength of alkali-activated ferronickel slag system. Cem. Concr. Compos. 2021, 123, 104179. [CrossRef]

4. Gu, F.; Peng, Z.; Zhang, Y.; Tang, H.; Ye, L.; Tian, W.; Liang, G.; Lee, J.; Rao, M.; Li, G. Thermodynamic Characteristics of Ferronickel Slag Sintered in the Presence of Magnesia. In Characterization of Minerals, Metals, and Materials; Springer: Berlin/Heidelberg, Germany, 2019; pp. 379-388.

5. Kuri, J.C.; Majhi, S.; Sarker, P.K.; Mukherjee, A. Microstructural and non-destructive investigation of the effect of high temperature exposure on ground ferronickel slag blended fly ash geopolymer mortars. J. Build. Eng. 2021, 43, 103099. [CrossRef]

6. Kuri, J.C.; Sarker, P.K.; Shaikh, F.U.A. Sulphuric acid resistance of ground ferronickel slag blended fly ash geopolymer mortar. Constr. Build. Mater. 2021, 313, 125505. [CrossRef]

7. Komnitsas, K.; Zaharaki, D.; Bartzas, G. Effect of sulphate and nitrate anions on heavy metal immobilisation in ferronickel slag geopolymers. Appl. Clay Sci. 2013, 73, 103-109. [CrossRef]

8. Bouasria, M.; Babouri, L.; Khadraoui, F.; Chateigner, D.; Gascoin, S.; Pralong, V.; Benzaama, M.-H.; Orberger, B.; El Mendili, Y. Insight into the partial replacement of cement by ferronickel slags from New Caledonia. Eur. J. Environ. Civ. Eng. 2020, 1-19. [CrossRef]

9. Choi, S.-J.; Kim, J.-H.; Bae, S.-H.; Oh, T.-G. Effect of Fly Ash on Compressive Strength, Drying Shrinkage, and Carbonation Depth of Mortar with Ferronickel-Slag Powder. Appl. Sci. 2021, 3, 1037. [CrossRef]

10. Cosme, J.; Fernandes, G.; Fernandes, D.P. Utilization of ferronickel slag in hot mix asphalt. REM-Int. Eng. J. 2021, 1, 19-26. [CrossRef]

11. Nguyen, Q.D.; Castel, A.; Kim, T.; Khan, M.S.H. Performance of fly ash concrete with ferronickel slag fine aggregate against alkali-silica reaction and chloride diffusion. Cem. Concr. Res. 2021, 139, 106265. [CrossRef]

12. Saha, A.K.; Khan, M.N.N.; Sarker, P.K. Value added utilization of by-product electric furnace ferronickel slag as construction materials: A review. Resour. Conserv. Recycl. 2018, 134, 10-24. [CrossRef]

13. Yang, L.; Peng, Z.; Huang, Y.; Wang, L.; Zheng, L.; Rao, M.; Li, G.; Jiang, T. Co-utilization of ferronickel slag and fly ash cenosphere for production of superior thermal insulation materials. Ceram. Int. 2021, 7, 10019-10026. [CrossRef]

14. Wang, W.; Chen, J.; Yu, J.; Zhou, L.; Dai, S.; Tian, W. Adjusting the melting and crystallization behaviors of ferronickel slag via partially replacing of $\mathrm{SiO}_{2}$ by $\mathrm{B}_{2} \mathrm{O}_{3}$ for mineral wool production. Waste Manag. 2020, 111, 34-40. [CrossRef]

15. Kim, Y.; Kim, M.; Sohn, J.; Park, H. Applicability of gold tailings, waste limestone, red mud, and ferronickel slag for producing glass fibers. J. Clean. Prod. 2018, 203, 957-965. [CrossRef]

16. Wang, W.; Dai, S.; Zhou, L.; Zhang, T.; Tian, W.; Xu, J. Effect of $\mathrm{B}_{2} \mathrm{O}_{3}$ on the properties of ferronickel melt and mineral wool. Ceram. Int. 2020, 9, 13460-13465. [CrossRef]

17. Yun, J.-J.; Kang, B.-H.; Kang, S.-W.; Kim, S.-Y.; Seo, D.-C.; Cho, J.-S. Effect of fertilizers using Ferro-nickel slag on Chinese cabbage growth and soil chemical properties. Korean Soc. Soil Sci. Fertil. 2018, 51, 204-210. 
18. Peng, Z.; Wang, L.; Gu, F.; Tang, H.; Rao, M.; Zhang, Y.; Li, G.; Jiang, T. Recovery of chromium from ferronickel slag: A comparison of microwave roasting and conventional roasting strategies. Powder Technol. 2020, 372, 578-584. [CrossRef]

19. Zulhan, Z.; Agustina, N. A novel utilization of ferronickel slag as a source of magnesium metal and ferroalloy production. $J$. Clean. Prod. 2021, 292, 125307. [CrossRef]

20. Liu, Y.; Qin, Z.; Chen, B. Experimental research on magnesium phosphate cements modified by red mud. Constr. Build. Mater. 2020, 231, 117131. [CrossRef]

21. Liao, J.; Lu, S.; Duan, X.; Xie, Y.; Zhang, Y.; Li, Y.; Zhou, A. Affecting mechanism of chitosan on water resistance of magnesium phosphate cement. Int. J. Appl. Ceram. Technol. 2018, 2, 514-521. [CrossRef]

22. Haque, M.A.; Chen, B. Research progresses on magnesium phosphate cement: A review. Constr. Build. Mater. 2019, 211, 885-898. [CrossRef]

23. Eliaz, N.; Metoki, N. Calcium Phosphate Bioceramics: A Review of Their History, Structure, Properties, Coating Technologies and Biomedical Applications. Materials 2017, 4, 334. [CrossRef]

24. Zhang, J.; Liu, W.; Schnitzler, V.; Tancret, F.; Bouler, J.-M. Calcium phosphate cements for bone substitution: Chemistry, handling and mechanical properties. Acta Biomater. 2014, 3, 1035-1049. [CrossRef]

25. Liu, Y.; Chen, B.; Qin, Z.; Pen, D.; Aminul Haque, M. Experimental research on properties and microstructures of magnesium-iron phosphate cement. Constr. Build. Mater. 2020, 257, 119570. [CrossRef]

26. Sagadin, C.; Luidold, S.; Wagner, C.; Pichler, C.; Kreuzer, D.; Spanring, A.; Antrekowitsch, H.; Clarke, A.; Clarke, K. Thermodynamic Refractory Corrosion Model for Ferronickel Manufacturing. Metall. Mater. Trans. B 2021, 2, 1052-1060. [CrossRef]

27. Thompson, A.; Saha, A.K.; Sarker, P.K. Comparison of the alkali-silica reactions of ferronickel slag aggregate in fly ash geopolymer and cement mortars. Eur. J. Environ. Civ. Eng. 2019, 26, 891-904. [CrossRef]

28. Yang, N.; Shi, C.; Yang, J.; Chang, Y. Research Progresses in Magnesium Phosphate Cement-Based Materials. J. Mater. Civ. Eng. 2014, 10, 04014071. [CrossRef]

29. Fan, S.; Chen, B. Experimental study of phosphate salts influencing properties of magnesium phosphate cement. Constr. Build. Mater. 2014, 65, 480-486. [CrossRef]

30. Kuri, J.C.; Khan, M.N.N.; Sarker, P.K. Workability, strength and microstructural properties of ground ferronickel slag blended fly ash geopolymer mortar. J. Sustain. Cem. Based Mater. 2020, 2, 1-18. [CrossRef]

31. Sakkas, K.; Panias, D.; Nomikos, P.P.; Sofianos, A.I. Potassium based geopolymer for passive fire protection of concrete tunnels linings. Tunn. Undergr. Sp. Tech. 2014, 43, 148-156. [CrossRef]

32. Gu, F.; Peng, Z.; Tang, H.; Ye, L.; Tian, W.; Liang, G.; Rao, M.; Zhang, Y.; Li, G.; Jiang, T. Preparation of Refractory Materials from Ferronickel Slag. In Characterization of Minerals, Metals, and Materials; Springer: Berlin/Heidelberg, Germany, 2018 ; pp. 633-642.

33. Ostrowski, N.; Roy, A.; Kumta, P.N. Magnesium Phosphate Cement Systems for Hard Tissue Applications: A Review. ACS Biomater. Sci. Eng. 2016, 7, 1067-1083. [CrossRef] [PubMed]

34. Xiao, H.; Xing, S.; Wu, C. Preparation of Magnesium Phosphate Cement and Application in Concrete Repair. In Proceedings of the 2nd International Conference on Materials Engineering and Industrial Applications, Phuket, Thailand, 6-7 August 2017; EDP Science: Ulys, France, 2018.

35. Zhang, Q.; Cao, X.; Ma, R.; Sun, S.; Fang, L.; Lin, J.; Luo, J. Solid waste-based magnesium phosphate cements: Preparation, performance and solidification/stabilization mechanism. Constr. Build. Mater. 2021, 297, 123761. [CrossRef]

36. Sun, D.; Wu, K.; Kang, W.; Shi, H.; Li, S. Characterisation of water stability of magnesium phosphate cement blended with steel slag and fly ash. Adv. Cem. Res. 2020, 6, 251-261. [CrossRef]

37. Ruan, W.; Liao, J.; Li, F.; Gu, X.; Zhou, A.; Xie, Y. Effects of water purifying material waste and red mud on performance of magnesium phosphate cement. Constr. Build. Mater. 2021, 303, 124563. [CrossRef]

38. Jiang, Y.; Ahmad, M.R.; Chen, B. Properties of magnesium phosphate cement containing steel slag powder. Constr. Build. Mater. 2019, 195, 140-147. [CrossRef]

39. Luo, Z.; Ma, Y.; Mu, W.; Liu, J.; He, J.; Zhou, X. Magnesium phosphate cement prepared with electric furnace ferronickel slag: Properties and its hydration mechanism. Constr. Build. Mater. 2021, 300, 123991. [CrossRef]

40. Pang, B.; Liu, J.; Wang, B.; Liu, R.; Yang, Y. Enhancement of magnesium phosphate cement solidification of Pb2+ by K-struvite whisker in lead-contaminated solution. J. Clean. Prod. 2021, 320, 128848. [CrossRef]

41. Mestres, G.; Ginebra, M.P. Novel magnesium phosphate cements with high early strength and antibacterial properties. Acta Biomater. 2011, 4, 1853-1861. [CrossRef]

42. Li, H.; Yao, Q.Z.; Wang, Y.Y.; Li, Y.L.; Zhou, G.T. Biomimetic synthesis of struvite with biogenic morphology and implication for pathological biomineralization. Sci. Rep. 2015, 5, 7718. [CrossRef]

43. Zhang, T.; Wu, X.; Li, H.; Tsang, D.C.W.; Li, G.; Ren, H. Struvite pyrolysate cycling technology assisted by thermal hydrolysis pretreatment to recover ammonium nitrogen from composting leachate. J. Clean. Prod. 2020, 242, 118442. [CrossRef]

44. Stefov, V.; Šoptrajanov, B.; Spirovski, F.; Kuzmanovski, I.; Lutz, H.D.; Engelen, B. Infrared and Raman spectra of magnesium ammonium phosphate hexahydrate (struvite) and its isomorphous analogues. I. Spectra of protiated and partially deuterated magnesium potassium phosphate hexahydrate. J. Mol. Struct. 2004, 689, 1-10. [CrossRef]

45. Zhang, T.; Ding, L.; Ren, H.; Xiong, X. Ammonium nitrogen removal from coking wastewater by chemical precipitation recycle technology. Water Res. 2009, 20, 5209-5215. [CrossRef] 
46. Wang, N.; Yu, H.; Bi, W.; Guan, Y.; Gong, W.; Zhang, N.; Wu, C. The Improvement Effects of $\mathrm{NaH}_{2} \mathrm{PO}_{4}$ and $\mathrm{KH}_{2} \mathrm{PO} 4$ on the Properties of Magnesium Oxysulfate Cement. J. Wuhan Univ. Technol. Mater. Sci. Ed. 2021, 1, 50-57. [CrossRef]

47. Colorado, H.A.; Singh, D. High-sodium waste streams stabilized with inorganic acid-base phosphate ceramics fabricated at room temperature. Ceram. Int. 2014, 7, 10621-10631. [CrossRef]

48. Soudée, E.; Péra, J. Mechanism of setting reaction in magnesia-phosphate cements. Cem. Concr. Res. 2000, 2, 315-321. [CrossRef] 